\title{
Predicting ground subsidence due to long term oil/gas production in a Niger Delta basin, Nigeria: implications for $\mathrm{CO}_{2}$ EOR and geosequestration
}

Fidelis Ankwo Abija ( $\square$ fidelabija@yahoo.co.uk)

Rivers State University of Science and Technology https://orcid.org/0000-0001-5177-6560

Tamunoene. K. S. Abam

Rivers State University of Science and Technology

\section{Research Article}

Keywords: production, pore pressure depletion, reservoir compaction, subsidence

Posted Date: April 30th, 2021

DOI: https://doi.org/10.21203/rs.3.rs-357959/v1

License: @ (i) This work is licensed under a Creative Commons Attribution 4.0 International License. Read Full License 


\section{Abstract}

Reservoir pressure depletion with production leading to porosity loss, compaction and surface subsidence are the effect of effective stress changes and the imposition of the overburden stress which was partly supported by the fluids on the rock grain skeleton. Ground subsidence is associated with environmental hazards, failure of operational facilities and damages to infrastructures amounting to huge economic losses. In this studies, subsidence has been assessed using the Geertsma nucleus of strain based on predicted reservoir pressure. Depletion was estimated as percentage pore pressure dissipation and dynamically derived geomechanical and petrophysical rock properties determined. Reservoir porosity vary from $15 \%-32 \%$, shale volume from $11.2 \%-88 \%$, bulk compressibility range from $2.52-2.53 \times 10^{-6} / \mathrm{mPa}$, and uniaxial compaction coefficient $1.15-1.8 \times 10^{-6} / \mathrm{mPa}$. The vertical compaction in a typical reservoir interval with a thickness of $31.0 \mathrm{~m}$ varies from $0.002 \mathrm{~mm}$ to $0.05 \mathrm{~mm}$ at $10 \%$ formation pressure depletion, $-0.005 \mathrm{~mm}$ to $0.27 \mathrm{~mm}$ at $50 \%$ formation pressure drawdown and 0.007 to $0.53 \mathrm{~mm}$ at $99 \%$ production and reservoir pressure dissipation. surface subsidence would range from $0.045 \mathrm{~mm}$ to $0.35 \mathrm{~mm}$ at $10 \%$ pressure depletion, $0.058 \mathrm{~mm}$ to $1.8 \mathrm{~mm}$ at $50 \%$ pressure depletion and $0.045 \mathrm{~mm}$ to $-3.47 \mathrm{~mm}$ at full reservoir pressure drawdown. At a distance of $92.45 \mathrm{~km}$ from the Niger Delta coastline, subsidence in the oilfield can still spread to the coastline, the deformation causing damages to the environment, operational facilities and infrastructures that amount to huge economic losses to the operators and government. We recommend the use of $\mathrm{CO}_{2}$ in EOR to maximize production, mitigate subsidence through ground rebound and keep carbon securely sequestered.

\section{Paper Highlights}

- Reservoir porosity vary from $15 \%-32 \%$, shale volume from $11.2 \%$ - $88 \%$, bulk compressibility range from $2.52-2.53 \times 10^{-6} / \mathrm{mPa}$, and uniaxial compaction coefficient $1.15-1.8 \times 10^{-6} / \mathrm{mPa}$.

- Field wide subsidence varies from -1.34 to $-1.65 m$ at $10 \%$, from $4.7 m-7.0 m$ at $50 \%$, and from $6.3 \mathrm{~m}-15.5 \mathrm{~m}$ at $90 \%$ reservoir pressure depletion.

- The reservoir compaction and subsidence increased linearly with production induced formation pressure depletion and varies within the oilfield depicting variable rates of production and stress change

- The vertical compaction and ground surface subsidence can be predicted using the linear regression equations $\Delta \mathrm{H}=0.009 \Delta \mathrm{P}_{\mathrm{p}}+0.009$ and $\mathrm{S}=0.0588 \Delta \mathrm{P}_{\mathrm{p}}+0.0632$ with a $60 \%$ correlation.

- At a distance of $92.45 \mathrm{~km}$ from the Niger Delta coastline, subsidence in the oilfield can still spread to the coastline, the deformation causing damages to the environment, operational facilities and infrastructures that amount to huge economic losses to the operators and government.

- We recommend the use of $\mathrm{CO}_{2}$ in EOR to maximize production, mitigate subsidence through ground rebound and keep carbon securely sequestered. 


\section{Introduction}

Production of oil/gas results in pore pressure dissipation, loss of reservoir porosity and compressibility due to reservoir scale effective stress. Formation pressure dissipation induces changes in the reservoir stress field that causes the rock matrix to support a greater portion of the overburden stress originally borne by the reservoir fluids (Jones et al., 1987). This, Bruno and Bovberg, (1992) noted results from the removal of the support provided by the pore fluid as the pore pressure declines while the overburden load remains constant or rather increases if deposition is still continuing. The overburden stress remains constant because the reservoir is horizontal, infinite in extent and finite in thickness (Zoback, 2007) while formation pressure decreases phenomenally inducing in situ stress change and reduction in the vertical thickness of the producing formation. The effective (grain to grain contact) stress changes can also alter the normal and shear stresses on the rock framework (Jones et al., 1987; Riel et al. 2018) causing the rock to deform and change its shape, size and volume (Ali et al. 2003; Cook et al. 2007) in order to equilibrate under the new stress conditions. Fjaer et al. (2008) also observed that the rock alterations may include changes in volume, geometry, permeability, porosity, compressibility, strength characteristics, elasticity and fluid flow paths. The poro-elastic deformation of reservoir rocks is influenced by their mineralogy, porosity, depth of burial, pore pressure, effective stress, tectonics and temperature. Reservoir compaction causes changes in the rock fabric and the effects on reservoir compressibility can be irreversible under load because grain to grain contact in the rocks destroys the cement bonding by fracturing accompanied by elastic and or anelastic deformation closing the packing of individual grains by elastic distortions and strains under gravitational loading and fluids expulsion. It may also lead to grain sliding in shear, breakage and shifting (Abija, 2019a). The bulk reservoir rock compaction is the result of several micromechanical mechanisms (Hettema et al., 2000). Rock compressibility which quantifies the relative volumetric variation in reservoir pore space due to depletion induced stress changes (Zheng, 1993) relates changes in volume to changes in applied stress (Wolfe et al. 2005, Zimmermann, et al. 1986), porosity, elasticity and boundary conditions (Doornhof et al., 2006). It varies with pore fluid composition and depends on the cement bonding which imparts elasticity at low stress and yields under increased effective stress. Rock compressibility controls the degree of reservoir compaction because the reservoirs are more prone to deformation than the sideburden rocks due to their high porosity, compressibility and restriction of formation pressure change to the vicinity of the producing well and or the entire reservoir. While production induced reservoir deformations are restricted to the reservoir, the adjacent formations does not deform. Implicitly, the lateral strain in the reservoir under increased overburden load is prevented by an increase in the horizontal stress in the sideburden. Similarly, if stress changes in the stiff lateral sideburden can restrict the horizontal stress in the reservoir, the overburden and reservoir behave in the same way thus altering the effective compressibility of the reservoir. If both the overburden and underburden have equal stiffnesses, then the vertical strain required due to change in the effective stress cannot develop. In the depleting reservoirs, initial pore pressure will attempt to mobilize internal strains which will be partially balanced by the stress in the adjacent sideburden rocks. A very stiff overburden will cause a change in the total vertical stress such that the actual effective stress change is adequate to develop a strain state and the total vertical stress is re- 
distributed to the sideburden forming a stress arch in the overburden. The stress arch developed reduces the increase in effective stress over the reservoir thus increasing the load and vertical strains on the sideburden rocks. The degree of shielding depends on the reservoir depth, and geometry; and on the contrast in mechanical properties between the reservoir and the sideburden (Jones et al. 1992).

Overburden stiffness may come from two sources (1) very hard rocks with a high modulus where it will be prone to resist strain and change its internal stress state, and (2) the reservoir geometry (especially surface area) will interact with the stiffness of overlying rocks to resist displacement (smaller reservoirs are stiffer than large ones) (Jones et al. 1992).

The increase in effective vertical and horizontal stresses at conditions close to the stress ratio results in compaction and continuous burial diagenesis that drives the sediment towards higher mechanical and chemical thermodynamic stability. Depletion induced reservoir compaction is strongly influenced by the stress path (Hettema et al. 2000; Zoback, 2007) as an index of in situ stress evolution before and after production. Stress path controls the mode of deformation and or failure. Zoback, (2007) noted that a sufficiently low or high stress path value implies that the rock will fail under shear or undergo compaction.

Compaction mobilizes vertical elasto-plastic strains in the reservoir due to reduction in pore volume and/or permeability destroying elastic bonding at yield. The benefits of reservoir compaction include more effective hydraulic fracturing and compaction drive enhanced production and recovery. Excessive groundwater withdrawal from the overlying aquifers at shallower depths in densely populated areas also increases the rate of compaction. Reservoir compaction and associated ground subsidence (Zoback, 2007, Holzer and Bluntzer, 1984, Abija et al. 2020), is detrimental due its ability to cause earth fissures, faults and strain on infrastructures (Riel et al. 2017), induced seismicity (van Thienen -Visser et al. 2015; de Waal et al. 2013; Grasso, 1992, Segall, 1989, Zoback, 2007; Yerkes, 1976), wellbore and casing collapse (Bruno, 2001), reservoir seal breach, structural permeability enhancement and fluid migration into unwanted zones (Cox, 2010, Sibson, 1996; Wiprut and Zoback, 2000), wellbore instability (Bruno, 2001) induced fault activation and or reactivation of pre-existing faults both of which are associated with seismicity (Zoback and Zinke, 2002, Grasso, 1992; Zoback, 2007), sea level rise, coastal flooding and erosion (Humphries, 2001, Abija et al. 2020a) and flood vulnerability (Abija et al. 2020b).

The compaction of subsurface formations can be transferred to vertical and lateral ground surface displacements which magnitude is directly related to the compaction in lateral and depth wise extents (Bruno, 2001). The primary indicator of reservoir compaction is a lowering and sinking of the ground surface into its surrounding environment (Abija, et al. 2020, Doornhof et al. 2006). Fluid extraction and its accompanying formation pressure depletion are generally accepted as the major causative mechanisms of land subsidence (Allen and Mayuga, 1971). It forms subsidence bowls which are generally wider than the compacting area, the amount of spreading depending on material properties of the overburden and the depth of the compacting formation (Doornhof et al. 2006). Subsidence mechanisms includes compaction, shear; consolidation pressure and consolidation path (Blyth and de Freitas, (1984). 
Ground subsidence in oil/gas fields have been reported across the world notably in the Goose Creek field in Texas in the late 1910s and in the 1920s and the Bolivar oil field in Venezuela (Fjaer et al. 2008), the Wilmington field in Long Beach, California (Kodsloff et al. 1980), the Ekofisk and Valhall reservoirs in the Norwegian sector of the North Sea, and the Groningen gas field onshore and offshore the Netherlands (Jones et al. 1992), the San Joachim valley, California, (Poland 1984), onshore and offshore Ravena area of Italy (Bertoni et al. 1995) and South Belridge field (Temizel et al. 2016). In the Goose Creek oilfield, Houston Texas, USA, Pratt and Johnson, (1926) found the volume of ground surface subsidence to have amounted to $20 \%$ of the oil/gas production.

Anthropogenic ground surface subsidence in oil/gas production can be predicted based on the geophysical properties of the reservoir and overlying overburden rocks (Keteclaar, 2009). The theoretical basis for its prediction is premised on compaction at depth due to pressure depletion causing spatio temporal surface displacements that extends beyond the surface projection of the compacting zone (Geerstma, 1973). Methods include analytical (Geerstma, 1973), numerical (Sroka and Hejmanowski, 2006) and finite element methods (Orlic et al., 2001). In the nucleus of strain method of Geerstma, (1973), the assumptions are that the overburden is uniform and elastic, the reservoir is built of nuclei of strain of small and finite volumes, and the volumetric strain at a point in a reservoir caused by pressure reduction is treated as a centre of compression in an elastic half space that produces a displacement field at the surface. Method also assumes homogeneous and linear elastic behavior of the reservoir rock with the same material properties and the ground surface subsidence is derived by integrating all the compression points over the reservoir (Bruno, 1992).

In the assessment, geomechanical models are integrated with reservoir properties obtained from laboratory measurements as exemplified by Narongsirikul et al. (2013). This often requires inputs on the mechanical behavior of the reservoir and sideburden rocks, depletion induced stress path, dimensions and depths of the reservoir and overburden; and model upscaling. Traditionally, the prediction of reservoir rock compaction is based on laboratory experiments conducted under uniaxial conditions in which no lateral strains are allowed under depletion (Hettema et al 2000) but due to the lack of rock cores for static laboratory test, dynamic methods relying on geophysically derived data in estimating the gomechanical properties needed as model input parameters are widely applicable. Dynamically derived geomechanical properties also require calibration and or validation with statically determined laboratory test results thus laboratory programs on cored samples is highly recommended.

Zheng, (1993) identified principal lithological and structural characteristics of subsiding formations to include unconsolidated sediments that lack appreciable cementation, Miocene age or younger with porosity varying from $20-40 \%$; formation thickness greater than $50 \mathrm{~m}$ with structurally weak overburden sediments, tension type faulting often with a graben structure, interbedded sands with shales/clays, fine silts or siltstones and pore pressure is greatly reduced by voluminous production. Fjaer et al. (2008) and Allen and Mayuga, (1971) observed that there must be significant reservoir pressure drop due to production, the reservoir rocks must be highly compressible; it must have a considerable thickness with significant compaction in the pay zone which must not be shielded by the overburden rocks. 
The Niger delta, one of the largest deltas, is estimated to be producing 2 million barrels of oil and 3 million standard cubic feet of gas daily at a depth range of $2.7-8 \mathrm{~km}$ (Abam, 2001) within the intervening sandstone and shales of the Agbada Formation. The basin has been adduced to be sinking at rates of $2.5 \mathrm{~cm} / \mathrm{yr}$. (Fubara, 1986), $12.5 \mathrm{~cm} / \mathrm{yr}$. (lbe, 1988), and $66.67 \mathrm{~mm} / \mathrm{yr}$. to $200.0 \mathrm{~mm} / \mathrm{yr}$. (Uko et al. 2018). A recent studies by Abija et al. (2020) integrating well head elevation measurements and ASTER digital elevation models extracted ground elevations predicted subsidence rates of $56 \mathrm{~cm} / \mathrm{yr}$. above the producing oil/gas field which is $92.45 \mathrm{~km}$ from the Niger Delta coastline and recommended investigation into production induced reservoir compaction and subsurface subsidence due to formation pressure dissipation as basis for understanding the contribution of oil/gas production amidst other causative mechanisms of ground subsidence. This research was carried out to fill the knowledge gap and recommend management strategies for mitigating subsidence and associated environmental hazards and damages to engineering infrastructures and operational facilities of the operators in the Niger Delta basin.

\section{Study Area}

The study area is located in the onshore coastal swamp within $0513.2208^{\circ} \mathrm{N}$ and $00641.0107^{\circ} \mathrm{E}$ situated in the Gulf of Guinea (Fig. 1). The basin one of the largest regressive tertiary deltas in a passive margin is estimated to cover an area of $300,000 \mathrm{~km}^{2}$ with a sediment volume of $500,000 \mathrm{~km}^{3}$ (Hospers, 1965) and a sediment thickness of over $10 \mathrm{~km}$ in the basin depocenter (Kaplan et al., 1994). A southwestward progradation during basin evolution formed depobelts that represent the most active portions of the delta at each stage of its evolution (Doust and Omatsola, 1990, Kulke 1995). Estimates of recoverable hydrocarbons are about 34.5 billion barrels of oil and 93.8 trillion cubic feet of gas (14.9 billion barrels of oil equivalent) per unit volume of basin-fill. The stratigraphic sequences of the basin are subdivided into three units namely Akata, Agbada and Benin formations each of which range from Tertiary to Recent (Short and Stauble, 1967). The onshore portion of the Niger Delta Province is delineated by the geology of southern Nigeria and southwestern Cameroon. The Benin flank- an East-North East trending hinge line south of the West Africa basement massif marks the boundary north westward while Cretaceous outcrops of the Abakaliki High forms the northeastern boundary. The Calabar flank, a hinge line bordering the adjacent Precambrian, forms the East- South-East limit of the basin. Offshore, the basin is bounded by the Cameroon volcanic line to the east, the eastern boundary of the Dahomey basin (the eastern-most West African transform-fault passive margin) to the west, and the two-kilometer sediment thickness contour or the $4000 \mathrm{~m}$ bathymetric contour in areas where sediment thickness is greater than two kilometers to the south and southwest. This forms the geologic extent of the Tertiary Niger Delta (AkataAgbada) Petroleum System

Tectonically, basin evolution was controlled by Cretaceous fracture zones formed during the triple junction rifting and opening of the South Atlantic which palaeo-indicators include trenches and ridges in the deep Atlantic and cutting into the continent (Abija, 2019b). Fracture zone ridges subdivide the margin into individual basins and forms the boundary faults of the Cretaceous Benue - Abakaliki trough 
extending far into the West African shield. The trough, an aulacogen of the triple junction rift system started opening in the Late Jurassic and persisted into the Middle Cretaceous (Lehner and De Ruiter, 1977) diminishing in the Niger delta in the Late Cretaceous. This was followed by gravity tectonism as the primary deformational process after cessation of rifting and induced deformation in response to shale mobility (Kulke, 1995). Shale diapirism due to loading of poorly compacted, over-pressured, prodelta and delta-slope clays resulted in the deposition of the the continental intercalaire, Akata Formation by higher density delta front sands of the Agbada Formation. This was followed by slope instability caused by lack of lateral basinward support for the under-compacted delta slope clays of the Akata Formation. Gravity tectonics indexed by structures such as shale diapirs, roll-over anticlines, collapsed growth fault crests, back-to-back features, and steeply dipping closely spaced flank faults (Evamy et al. 1978) completed the pro-deltaic deposition before deposition of the Benin Formation. These faults mostly offset different parts of the Agbada Formation and flatten into detachment planes near the top of the Akata Formation. Deposition of the formations in offlapping siliciclastic sedimentation cycles $30-60 \mathrm{Km}$ wide, prograde southwestward $250 \mathrm{Km}$ over oceanic crust into the Gulf of Guinea (Stacher 1995) and synsedimentary faulting occurred in response to variable rates of subsidence and sediment supply (Doust and Omatsola 1990). Subsidence and supply rates interplay resulted in deposition of discrete depobelts. When further crustal subsidence could no longer be accommodated, the centre of sediment deposition shifted seaward forming new depobelt each marking a break in regional dip of the delta bounded landward by growth faults and seaward by large counter regional faults or the growth fault of the next seaward belt (Evamy et al 1978). Each depobelt is a separate unit recognized by its own sedimentation, deformation, and petroleum history. Doust and Omatsola (1990) describe three depobelt provinces based on structure. The northern delta province which overlies relatively shallow basement has the oldest growth faults that are generally rotational, evenly spaced with increase steepness seaward. The central delta province has depobelts with well-defined structures such as successively deeper rollover crests that shift seaward for any given growth fault. The distal delta province is the most structurally complex due to internal gravity tectonics on the modern continental slope. The Niger Delta is ranked the twelfth richest in petroleum resources, with $2.2 \%$ of the world's discovered oil and $1.4 \%$ of the world's discovered gas by the USGS's World Energy Assessment (Klett et al., 1997). Most fields consist of series of reservoirs containing oil of varying composition with different gas/oil ratios and gas caps. Many reservoirs are overpressured and primary production is mainly from gas expansion (Kulke, 1995). Petroleum reservoirs in the Niger Delta are basically sandstone and unconsolidated sands controlled by depositional environment and burial depth in the Agbada Formation. Reservoir rocks range in age from Eocene to Pliocene often stacked with thickness ranging from less than 15 meters to $10 \%$ having greater than $45 \mathrm{~m}$ (Evamy et al 1978). Structural traps and seals are predominant although stratigraphic traps are common. Structural traps developed during synsedimentary deformation of the Agbada paralic sequence with structural complexity increasing from the north to the south in response to increasing instability of the under-compacted, over-pressured shale (Stacher 1995). The primary seal rock, the interbedded shale within the Agbada Formation provides three types of seals - clay smears along faults, interbedded sealing units against which reservoir sands are juxtaposed due to faulting, and vertical seals (Doust and Omatsola, 1990). On the flanks of the delta, stratigraphic traps are likely as important as structural traps 
(Beka and Oti, 1995) while major erosional events of early to middle Miocene age formed canyons now clay-filled on the flanks of the delta.

\section{Materials And Methods}

The study materials include geophysical well log data including resistivity, gamma ray, density and sonic logs; well head x, y, z coordinates sourced from Total E \& P Nig. Ltd, through the Department of Petroleum resources, Port Harcourt, Nigeria and remotely acquired advanced spaceborne thermal emission and reflection radiometer's digital elevation models of years 2000 and 2018. Data analysis involved quality control in excel spreadsheet and correlation of the gamma ray and resistivity geophysical well logs in Petrel 2012 software to establish subsurface formation's lithological variation with depth. Determination of the rock's elastic properties was achieved using density and sonic logs. The research however suffered the limitation of lack of rock cores from the reservoirs for static laboratory test and determination of mechanical properties for model validation. Log correlation also depicted two fault planes striking NE SW and NW - SE forming a graben and indicating conditions for assessment of subsurface compaction subsidence (Zheng, 1993). The ASTER digital elevation model images of 2000 and 2018 were analyzed in ArcGIS 10.3. Ground control points were established by adding the well's X. Y and Z coordinates to provide the integrity of the map of the study area. Image processing to improve the quality was accomplished on the basis of well distributed ground control points located on both the images and the map of the area following the recommendations by Olmanson et al., (2001). Geometric rectification of each image followed standard procedures in the ArcGIS 10.3 software correcting pixel location errors to establish correspondence between ground and the exact locations on the image. Images were enhanced through linear stretching technique of the false colour composites to the different spectral bands thus modifying the distribution and range of digital numbers of the image pixels to improve coverage of a larger range within the stretched image (Lillesand et al., 2008). Ortho-rectified ground elevation values were then extracted from the digital elevation models of years 2000 and 2018 respectively. Extracted elevations were compared against well head ground elevations measured in 1982 when wells were drilled and completed prior to hydrocarbon production. Results of the digital elevation models were presented as elevation maps of the oilfield while extracted ground elevations and predicted subsurface compaction

and subsidence were contoured as maps and 3D surface elevation. Reservoir pressure depletion and the accompanying compaction and ground subsidence were evaluated in in a depth interval of $2620 \mathrm{~m}-$ $4150 \mathrm{~m}$.

\section{Estimation of reservoir compaction and subsidence}

Compaction can be characterized by the vertical strain $\left(\varepsilon_{v}\right)$ due to change in reservoir pressure depletion with production and the accompanying changes in reservoir height due to pressure drawdown relative to its initial height. Bruno, (2001) noted that reservoir compaction in vertical direction can be characterized by a compaction coefficient, $\mathrm{C}_{\mathrm{m}}$ in $\mathrm{mPa}^{-1}$ given in equation (1). 
$C_{m}=C_{b} \cdot(\underline{1+v})$.

$$
3(1-v)
$$

Where $\mathrm{C}_{\mathrm{b}}=$ bulk compressibility and equals the inverse of the rock bulk modulus $\left(\mathrm{K}_{\mathrm{b}}\right)$,

$C_{b}=1 / K_{b}$

$\mathrm{K}_{\mathrm{b}}=\mathrm{a} \rho_{\mathrm{b}}\left(1 / \Delta \mathrm{T}_{\mathrm{cma}}^{2}-4 / 3 \Delta \mathrm{T}_{\mathrm{sma}}^{2}\right)$

Where,

$\mathrm{a}=1.3464$,

$\rho_{\mathrm{b}}=\quad$ bulk density in $\mathrm{g} / \mathrm{cm}^{3}$

$\Delta \mathrm{T}_{\mathrm{cma}}=$ measured compressional sonic transit time of the rock matrix in $(\mu \mathrm{s} / \mathrm{ft})$

$\Delta \mathrm{T}_{\text {sma }}=$ measured interval shear sonic transit time of the rock matrix $(\mu \mathrm{s} / \mathrm{ft})$

$v=$ Poisson ratio

$v=0.5\left(V_{p} / V_{s}\right)^{2}-1 /\left(V_{p} / V_{s}\right)^{2}-1$

$V_{p}=P$-wave velocity

$V_{p}=304878 / \Delta T_{c}$

$\mathrm{V}_{\mathrm{s}}=$ Shear wave velocity

$V_{S}=304878 / \Delta T_{S}$

Pore pressure was predicted using Zhang, (2011) equation (8) and (9) adapted from Eaton (1972) and the Tingay et al (2009) exponential normal compaction trendline equation (7) using sonic transit times to derive the normal transit time, $\left(\Delta T_{n}\right)$.

$\Delta \mathrm{T}_{\mathrm{n}}=\Delta \mathrm{T}_{\mathrm{m}}+\left(\Delta \mathrm{T}_{\mathrm{ml}}-\Delta \mathrm{T}_{\mathrm{m}}\right) \mathrm{e}^{-\mathrm{cz}}$

Based on equation (7) (Zhang, 2011) modified Eaton's equation is

$\left.P_{p}=\sigma_{v}-\left(\sigma_{v}-P_{h y d}\right)\left(\Delta T_{m l}-\Delta T_{m}\right) e^{-c z} / \Delta T_{\text {log }}\right)^{3}$.

Where $\mathrm{Pp}=$ pore pressure, $\mathrm{OBG}=$ overburden gradient, $\mathrm{P}_{\text {hyd }}=$ normal or hydrostatic pressure, $\Delta \mathrm{T}_{\mathrm{m}}=$ compressional transit time in shale matrix normally $=70, \Delta \mathrm{T}_{\mathrm{ml}}=$ compressional transit time at mudline normally $=200, c$ is a constant that depends location and must be calibrated, $z=$ depth. Zhang's constant 
c was calibrated for the study area using leak off tests data to 0.00048 and 0.00038 for well 5 and 10 respectively.

The Eaton (1972) method of pore pressure prediction was also applied with sonic transit time. The method uses vertical overburden stress as in the equations (9).

$P_{P}=\sigma_{v}-\left(\sigma_{v}-P_{\text {hyd }}\right)\left(\Delta T_{n} / \Delta T_{\text {log }}\right)^{3.0}$

where $P_{p}$ is pore pressure; $\sigma_{\mathrm{v}}$ is the overburden stress, $P_{\text {hyd }}$ is hydrostatic or normal pore pressure; and the subscripts $n$ and log refer to the normal and measured values of resistivity $(R)$ and sonic delta-t $(\Delta T)$ at each depth. The normal transit time $\left(\Delta T_{n}\right)$ for well 11 was determined using the exponential trendline equation for the normal compaction curve as proposed by Tingay et al (2009). The equation was

$\Delta \mathrm{T}_{\mathrm{n}}=2.771830^{0.078 * \mathrm{Z}}$

Production pressures are not available therefore the pore pressure change $\left(\Delta \mathrm{P}_{\mathrm{p}}\right)$ was determined as a percentage of pore pressure dissipation in the production cycle from the predicted formation pressures.

The change in the vertical thickness of the reservoir due to formation pressure depletion (compaction) is given as (eqn. 11)

$\Delta \mathrm{H}=\mathrm{H} \cdot \mathrm{C}_{\mathrm{m}} \cdot \Delta \mathrm{P}_{\mathrm{p}}$

Where $\Delta \mathrm{P}_{\mathrm{p}}=$ pore pressure change in $\mathrm{mPa}$ and $\mathrm{H}=$ formation thickness in metres.

Equation (eqn. 12) proposed for formation subsidence in laterally extensive reservoirs where the reservoir radius is much greater than the reservoir thickness (R>>>H) (Geerstma, 1973) was adopted for prediction of the total magnitude of the subsidence due to fluids extraction from the reservoirs.

Subsidence $=\int_{0}{ }^{h} C_{m}(z) \Delta P_{p}(z) d z \ldots .$.

where the compaction coefficient $\left(\mathrm{C}_{\mathrm{m}}\right)$ at any depth $\mathrm{z}$ is defined in equation $1, \Delta \mathrm{P}(\mathrm{z})$ is the pore pressure change at depth $z, d z$ is the change in depth.

The vertical overburden stress superimposing gravitational load on the subsurface rocks and the vertical strain characterizing the compaction were estimated by integrating the formation density derived from measured density log data after filtering (eqn. 13) and equation (14) respectively.

$\sigma_{\mathrm{v}}=\int \rho_{\mathrm{b}} \mathrm{gz}(\mathrm{dz})$

$\varepsilon_{\mathrm{z}}=\mathrm{dz} / \mathrm{z}$

where, 
$\sigma_{v}=$ vertical overburden stress

$\rho_{b}=$ bulk density

$\mathrm{g}=$ gravitational acceleration

$z=$ depth

Equations (14) and (15) were used calculate the stress path evolution.

$\mathrm{K}_{\mathrm{o}}=(\mathrm{v} / 1-\mathrm{v})$

$A=\underline{a}(\underline{1-2 v})$.

$(1-v)$

Where,

$\mathrm{K}_{\mathrm{o}}=$ in situ stress path,

$v=$ Poissons ratio

$a=\quad$ Biots coefficient $=1-C_{r} / C_{b}$

$A=\quad$ Deletion induced stress path

$\mathrm{Cr}=1 /\left(\mathrm{apb}\left(1 / \Delta \mathrm{TC}_{\mathrm{ma}}{ }^{2}-4 / 3 \Delta \mathrm{TS}_{\mathrm{ma}}{ }^{2}\right)\right.$

\section{Results And Discussion}

\section{1: Reservoir characterization}

A correlation of wireline log data from three wells in the oil and gas field shows the typical interlayered sandstone and shale rock units of the Agbada Formation occurring at a depth interval of $2500-4300 \mathrm{~m}$ (Figure 2). Tectonic and lithostatic stress concentration, tensile fracturing and fracture connectivity induced shearing and kinematic displacement of the interconnected fractures in NE - SW and NW - SE directions formed listric faults which the accompanying synkinematic downwarping of the downwthrown block resulted in a grabben thereby creating favourable conditions (Zheng, 1993, Fjaer et al. 2008) for assessing subsurface reservoir compaction and subsidence. Reservoir thicknesses range from $30-$ 273 m with porosity varying from $15 \%-32 \%$ averaging $20 \%$ and shale volume from $11.2 \%-88 \%$ (Figure 3). Typical reservoir's bulk compressibility range from $2.52-2.53 \times 10^{-6} / \mathrm{mPa}$ (Figure 4) while the uniaxial compaction coefficient which relates to the reduction in reservoir thickness per unit stress increase in the vertical direction under constant rate of overburden loading and with prevention of radial deformation (Hassely van, 1992) range from $1.15-1.8 \times 10^{-6} / \mathrm{mPa}$ (Figure 5). The reservoir's Poisson 
ratio varies from $0.15-0.30$, moduli of elasticity and rigidity ranges from $7003.8 \mathrm{mPa}$ to $54,764.9 \mathrm{mPa}$ and $58.99 \mathrm{mPa}$ to $4845.6 \mathrm{mPa}$ respectively. Reservoir rock's angle of internal friction of $21^{\circ}-35^{\circ}$, cohesive strength of $6.0-10.34 \mathrm{mPa}$ and tensile strength from $1.28 \mathrm{mPa}$ to $5.60 \mathrm{mPa}$. Formation age is Oligocene - Miocene (Baulac et al., 1986)

Predicted initial reservoir pore pressure depicted a range of $0.18 \mathrm{mPa}-50 \mathrm{mPa}$ (Figure 5) and varying throughout the reservoir depending on initial pressure distribution, reservoir porosity and permeability, production and depletion rate, fluid properties. Production induced pressure dissipation calculated by percentage crude extraction during production as a proxy for reservoir depletion shows that at $10 \%$ production, the reservoir pressure varies from -0.1 to $-2.0 \mathrm{mPa}$. At $50 \%$ reservoir drawdown, pressure depletion would range from -0.15 to $-20.5 \mathrm{mPa}$ while a range of -0.1 to $-41.0 \mathrm{mPa}$ would occur at $99 \%$ cruse production when the reservoir is nearly fully depleted. The removal of these pressure under varying production rates across the oilfields, removes the support provided by the fluids thereby superimposing the entire overburden stress which is either constant or increasing (under continuous deposition) above the producing formations on the reservoir mineral skeleton and leading to vertical compactional deformation which degree is directly dependent on reservoir elasticity as a function of compressibility.

\subsubsection{Reservoir pressure depletion, compaction and subsidence}

Fluids (oil/gas and water) in subsurface reservoirs results in time depended deformation of the poroelastic solid thus necessitating thee prediction of reservoir compaction and the effects which may be visible as subsidence, faulting and associated seismicity and fault seal breach (Zoback, 2007). The vertical compaction in the reservoir interval with a thickness of $31.0 \mathrm{~m}$ under consideration varies from $0.002 \mathrm{~mm}$ to $0.05 \mathrm{~mm}$ at $10 \%$ formation pressure depletion, $-0.005 \mathrm{~mm}$ to $0.27 \mathrm{~mm}$ at $50 \%$ formation pressure drawdown and 0.007 to $0.53 \mathrm{~mm}$ at $99 \%$ production and reservoir pressure dissipation (Figure $6)$.

Correspondingly, the surface subsidence would range from $0.045 \mathrm{~mm}$ to $0.35 \mathrm{~mm}$ at $10 \%$ pressure depletion, $0.058 \mathrm{~mm}$ to $1.8 \mathrm{~mm}$ at $50 \%$ pressure depletion and $0.045 \mathrm{~mm}$ to $-3.47 \mathrm{~mm}$ at full reservoir pressure drawdown (Figure 7). The magnitude of the constant overburden stress which imposes the load on the reservoir rock varies from $60 \mathrm{mPa}$ to $80 \mathrm{mPa}$ (Figure 8). Bivariate relationships depict that the change in vertical thickness with pore pressure depletion is defined in equation (4.1) while the surface subsidence is predicted with equation (4.2) with a correlation coefficient 0.6.

$\Delta H=0.009 \Delta P_{p}+0.009$

$S=0.0588 \Delta P_{p}+0.0632$

Figures ( 9 and 10) and Table 4.2 presents the results of predicted reservoir subsidence on the basis of percentage formation pressure dissipation with oil/gas production. Subsurface compaction and subsidence in the reservoirs indicates a subsidence of -1.34 to $-1.65 \mathrm{~m}$ across the wells at $10 \%$ reservoir pressure dissipation (Table 1), from $4.7 \mathrm{~m}-7.0 \mathrm{~m}$ when the production has attained $50 \%$ due to reservoir 
pressure depletion (Table 4.2 and Figure 11 ) and $6.3 \mathrm{~m}-15.5 \mathrm{~m}$ at $90 \%$ reservoir pressure depletion (Table 4.2 and Figure 4.10). The reservoir compaction and subsidence increased linearly with production induced formation pressure depletion and varies within the oilfield depicting variable rates of production and stress change, geomechanical anisotropy and the presence of faults and fractures (Abija, et al. 2020). Figure 13a and 13b also indicates the presence of symmetrical subsidence bowls which index anthropogenic subsidence in fluid extraction, the bowl representative of the volume of oil/gas removed.

\section{Table 1: Summary of Depletion induced reservoir subsidence}

\begin{tabular}{|c|c|c|c|c|c|}
\hline \multirow[t]{2}{*}{ Well } & \multirow{2}{*}{$\begin{array}{l}\text { No of } \\
\text { Reservoirs }\end{array}$} & \multirow{2}{*}{$\begin{array}{l}\text { Reservoirs } \\
\text { Thickness } \\
\text { (m) }\end{array}$} & \multicolumn{3}{|c|}{ Reservoir subsidence $(\mathrm{m})$} \\
\hline & & & $\begin{array}{l}10 \% \\
\text { Depletion }\end{array}$ & $\begin{array}{l}50 \% \\
\text { Depletion }\end{array}$ & $\begin{array}{l}99 \% \\
\text { Depletion }\end{array}$ \\
\hline Well 5 & 12 & $12-273$ & 1.34 & 5.0 & 8.97 \\
\hline $\begin{array}{l}\text { Well } \\
10\end{array}$ & 8 & $17-398$ & 1.65 & 7.0 & 15.5 \\
\hline $\begin{array}{l}\text { Well } \\
11\end{array}$ & 13 & $17-255$ & 1.46 & 4.7 & 6.3 \\
\hline
\end{tabular}

\subsection{Ground subsidence above the oilfield}

The ground subsidence above the oilfield range from $-18.0 \mathrm{~m}$ on the east to $-24.0 \mathrm{~m}$ on the west forming a symmetrical subsidence bowl on the west of the oilfield (Figure 13). The symmetrical bowl of subsidence is visible in a dimensional ground surface model of the filed (Figures 14a and 14b) is indicative of the centre of fluid extraction from the subsurface formations as noted by Doornhof et al. (2006). Decrease in subsidence to the east of the oilfield is attributed to variable formation pressure depletion due to varying production, variation in mechanical response of the reservoir, anisotropy due to crustal faults and stress arching. Based on the magnitude of the ground surface subsidence, it is difficult to ascertain what percentage of the formation pressure has been dissipated since production figures are not available. However, land subsidence above the ground (Figures 14a and 14b) depicts symmetrical and wide area asymmetrical subsidence bowls above the oilfield supporting the assertion that subsidence is due to oil/gas production. It is difficult to ascertain at what level of production the reservoirs are, but a subsidence range of $-18.0 \mathrm{~m}$ to $-24.0 \mathrm{~m}$ above the oilfield, when compared to $6.3 \mathrm{~m}$ to $15.5 \mathrm{~m}$ reservoir compaction induced surface subsidence at $90 \%$ reservoir pressure drawdown, suggest that other causative mechanism such as fault movement, neotectonics and consolidation settlement of recent deposits contributes significantly to the magnitude of land subsidence in the coastal Niger Delta.

\subsection{Subsidence mitigation through improved production and climate change abatement}

Ground rebound and uplift which can be achieved through subsurface fluid injection is a known geotechnology for subsidence mitigation. Enhanced Oil Recovery's (EOR) technologies such as thermal/steam, $\mathrm{CO}_{2}$, waterflooding, and chemical injection are used to sweep oil/gas left behind in the 
reservoir. Carbon, the major culprit in temperature inversion in the stratosphere, ozone layer depletion and heating of the earth's atmosphere, exacerbating climatic change and in the Niger Delta region, gas flaring from production stacks has continued unabated. It's large amount as soot and its inherent due to its polycyclic aromatic hydrocarbons has been adduced to exceed the World Health Organization and local standards (Ede and Edokpa, 2015) with lethal carcinogenic and mutagenic effects on the lungs with increased exposure.

Current drive for cutting down greenhouse gas emissions to combat climate change through renewable energy sources by world governments has not achieved much because fossil fuels are still useful for driving heavy industrialization. Denney, (2011) noted that $\mathrm{CO}_{2}$ capture and secure geosequestration remains one of the greatest challenges facing the oil/gas industry and it has been identified to resolve the squeeze between fast growing global energy needs and global warming. Carbon capture, separation, and liquefaction for use in EOR to sweep oil left behind during production and keep the carbon securely sequestered in depleted geological formations, will mitigate ground subsidence and associated environmental hazards, maximize production for increased revenue to drive developmental projects, and achieve the sustainable development goals - SDG 3 (Health/Wellbeing), SDG 7 (Energy), SDG 9 (Innovation and infrastructure), SDG 11 (Cities and communities) and SDG 13 (climate change) (Abija, 2021). $\mathrm{CO}_{2}$ reservoirs occur naturally in subsurface geological formations demonstrating that it can be stored underground for millions of years (Olden, et al. 2014). The immediate geomechanical risk associated with the technology is reservoir seal breach, fault leakage, secondary migration and induced seismicity all occasioned by fault reactivation at high injection pressures capable generating shear stresses exceeding the frictional strength of the crustal faults that compartmentalize the reservoirs under the in situ stress field. $\mathrm{CO}_{2}$ EOR injection management plans can predictively quantify the maximum sustainable injection pressure and fault failure which can be covered in design using site specific conditions proving for environmental monitoring and protection is recommended for immediate implementation through effective legislation and commitment.

\section{Conclusion}

Oil and gas extraction is causing ground subsidence in addition to hydrocompaction and consolidation settlement of recent deposits and tectonics and the relative rise in sea level and loss of massive wetlands is caused by the subsidence. At a distance of $92.45 \mathrm{~km}$ from the Niger Delta coastline, well below the $800 \mathrm{~km}$ adduced by Zoback, (2007), subsidence in the oilfield under investigation can still spread to the coast. 
The ground deformation and damaging to the environment, operational facilities and infrastructures amount to huge economic losses to the operators and government. Potential induced seismicity due poro-elastic stress changes consequent upon formation pressure induced depletion is also feared as a possible phenomenon which is thought to be on the rise as crude extraction nears full reservoir pressure dissipation.

\section{Declarations}

\section{Acknowledgment}

The author would like to thank Total Exploration and production Nigeria Ltd and the Department of petroleum Resources, Port Harcourt, Nigeria for providing data for this research.

\section{Declaration}

We declare that this work is original research and has been published or submitted to any journal.

\section{References}

Abam T. K. S. (2001). Regional hydrological research perspectives in the Niger Delta. Hydrological Science Journal. 46(1); 13 - 25. 22.

Abija, F. A. (2021). Sustainable fossil energy production for mitigating of land subsidence and climate change: Case study of the Niger Delta, Nigeria. A paper presented at the $2^{\text {nd }}$ global webinar conference on earth Science and Climate Change, held January 14 - 15, 2021.

Abija, F. A, Abam, T. K. S., Teme, S. C. and Eze, C. L. (2020a). Relative sea level rise, coastline variability and coastal erosion in the Niger Delta, Nigeria: implications for climate change adaptation and coastal zone management. J. Earth Science Climatic Change 2020 11:9

Abija, F. A, Abam, T. K. S., Teme, S. C. and Eze, C. L. (2020b) Ground subsidence and intermontane topographic depressions above a producing oilfield: A link to flood vulnerability in the Niger Delta Basin, Nigeria. J. Earth Science Climatic Change 2020 11:9.

Abija, F. A.(2019a). Geomechanical property evolution and the mechanics of growth faulting in a Niger Delta oilfield, Nigeria. Int. J. of Geology and Earth Sci., Vol. 5, No. 2. Pp. 73 - 95.

Abija, F. A.(2019b). Paleokinematic reconstruction and wellbore breakout analysis of in situ stress orientation in a Niger Delta Oilfield: Implications for tectonic reactivation in Nigeria. Journal of Earth Sciences \& Environmental Studies 4(6) p:789-805

Allen, D. R. and Mayuga, M. N. (1971). The mechanics of compaction and rebound, Wilmington oilfield, Long Beach California, USA. Pp. 410 - 423. 
Ali, A. H. A, Brown, T, Delgado, R., Lee, D., Plumb, D., Smirnov, N., Marsden, R., Prado-Verlado, E., Ramsey, L., Spooner, D., Stone, T., Stouffer, T. 2003. Watching rocks change - Mechanical Earth Modeling. Oil Review - Summer. Pp. 22 - 39.

Baulac, J., Grosdidier, E. and Boutet, C. (1986). Wabi 10 biostratigraphy, (2015-4504 m). S. N. E. A. (P) Direction Exploration Report, Elf Petroleum Nigeria Limited /Geosciences, 13pages

Beka, F. T., and Oti, M. N. (1995). The distal offshore Niger Delta: frontier prospects of a mature petroleum province, in, Oti, M.N., and Postma, G., eds., Geology of Deltas: Rotterdam, A.A. Balkema, Pp. 237-241.

Bertoni W., Brighenti, G., Gambolati, G., Ricceri, G. and Vuillermin, F. (1995) Land subsidence due to gas production in the on and offshore natural gas fields of the Ravena area, Italy Proceedings of the fifth International symposium on land subsidence. The Hague, IAHS Pub. No. 234. Pp. $13-20$

Blyth, F. G. and de Freitas, M. H. (1982). A Geology for Engineers, 7th edn. Oxford: Butterwoth - Heineman, Imprint of Elsevier. 325 pages

Bruno MS (2001) Geomechanical analysis and decision analysis for mitigating compaction related casing damage. SPE 71695. Pp. 1-13. 5.

Bruno, M. S. (1992). Subsidence induced well failure. SPE Drilling Engineering, pp. 148 - 152

Bruno, M. S. and Boveberg, C. A. (1992). Reservoir compaction and surface subsidence above the Lost Hills Field, California. Ed. Tillerson and W. R. Wawersik: Rock Mechanics Proc. The $33^{\text {rd }}$ Us symposium, Sweeney Convention Centre, Santa Fe/New Mexico 3 - 5, June,

Cook J, Rene A F, Hasbo K, Green S, Judzis A, Martiu J W, Suarez-Rivera R, Jorg H, Hooyman P, Lee D, Noerth S, Sayers C, Koutsabelloulis N, Marsden R, Stage M G and Tan C P (2007), "Rocks Matter: Ground Truth in Geomechanics", Oil Review, pp. 3655.

Cox, S. F. (2010). The application of failure mode diagrams for exploring the roles of fluid pressure and stress states in controlling styles of fracture-controlled permeability enhancement in faults and shear zones. Geofluids, 10, 217-233.

Denney, D. (2011). CO2 storage capacity - combining geology, engineering and economics. JPT July 2011, Pp. $109-111$

de Waal, J. A, Muntendam-Bos, A. G. and Roest, J. P. A. (2015). Production induced subsidence and seismicity in the Groningen gas field - can it be managed? Proc. IAHS, 372, $129-139$.

Doornhof, D, Kristiansen, T. G., Nagel, N. B., Pattillo, P. D., Sayers, C. (2006) Compaction and Subsidence. Oilfield Review, Autum, 50-67. 
Doust H and Omatsola E (1990), “Niger Delta”, in J D Edwards and P. A. Santogrossi (Eds.), Divergent/passive Margin Basins, pp. 239-248, AAPG Memoir 48, Tulsa, AAPG.

Eaton, B. A. 1972. Graphical method predicts geopressure worldwide. World Oil, Vol. 182, Pp 51 - 56.

Ede, P.N. and Edokpa, D.O. (2015) Regional Air Quality of the Nigeria's Niger Delta. Open Journal of Air Pollution, 4, 7-15. http://dx.doi.org/10.4236/ojap.2015.41002

Evamy B D, Haremboure J, Kamerling P, Knaap W A, Molloy F A and Rowlands P H (1978), “Hydrocarbon Habitat of Tertiary Niger Delta”, AAPG Bull., Vol. 62, pp. 277-298.

Fjaer E, Holt RM, Horsrud P, Raaen AM, Risnes R (2008) Petroleum Related Rock Mechanics, Amsterdam, Elsevier.

Fubara D. M. J. (1986) Flood and erosion: Human contributions and remedial environmental policy. Mimeographed paper, Institute of Flood, Erosion, Reclamation and Transportation. Rivers State University of Science and Technology, port Harcourt, Nigeria.

Geerstma, J. (1973), Land Subsidence above compacting Oil and Gas Reservoirs. J. of Petroleum Technology, Vol. 25, pp. 734744.

Grasso, J.-R. 1992. Mechanics of seismic instabilities induced by the recovery of hydrocarbons. Pure and Applied Geophysics 139(3-4):507-534.

Hettema, M. H. H., Schutjens, P. M. T., Verboom, B. J. M., and Gussinklo, H. J. (2000). Production induced compaction of a sandstone reservoir: the strong influence of stress path. SPE Reservoir Evaluation and Engineering, Vol. 3(4), pp. $342-347$.

Holzer, T. L. and Bluntzer, R. L. (1984). Land subsidence near oil and gas fields, Houston, Texas. USGS paper $450-459$.

Hospers J (1965). Gravity field and structure of the Niger Delta, Nigeria, West Africa. Geological Society of American Bulletin, Vol. 76, pp. 407-422.

Humphries, L. (2001). A review of relative sea level rise caused by mining-induced subsidence in the coastal zone: some implications for increased coastal recession. Climate Research, Vol. 18: Pp. 147-156.

Ibe AC (1988) Coastline erosion in Nigeria. University of Ibadan, Nigeria.

Jones, M. E, Leddra, M. J., Goldsmith, A. S. and Edwards, D. (1992). The geomechanical characteristics of reservoirs and reservoir rocks, HSE - Offshore Technology Report, OTH 90, 333, pp. 1-202

Jones, M. E, Leddra, M. J and Addis, M. A. (1987). Reservoir compaction and surface subsidence due to hydrocarbon extraction. HMSO OTH 87276 pp. 175 
Kaplan A, Lusser C U and Norton I O (1994). Tectonic Map of the World, Panel 10, Tulsa, American Association of Petroleum Geologists, Scale 1:10,000,000.

Ketclaar, V. B. H. (2009). Subsidence monitoring techniques: Satellite radar interferometry, Remote sensing and digital image processing 14. Springer Science, 7-26 9.

Klett, T.R., Ahlbrandt, T.S., Schmoker, J.W., and Dolton, J.L., 1997, Ranking of the world's oil and gas provinces by known petroleum volumes: USGS Open-file Report-97- 463.

Kosloff D, Scott RF, Scraton J (1980) Finite element simulation of Wilmington oil field subsidence: linear and nonlinear modeling. Tectonophysics, 65 and 70.

Kulke H (1995), “Nigeria”, in H Kulke (Ed.) Regional Petroleum Geology of the World. Part II: Africa, America, Australia and Antarctica, pp. 143-172, Gebrüder Borntraeger, Berlin.

Lehner P and De Ruiter P A C (1977), Structural History of Atlantic Margin of Africa. American Association of Petroleum Geologists Bulletin, Vol. 61, pp. 961-981.

Lillesand T, Kiefer R, Chipman J (2008). Remote sensing and image processing Interpretation. 6th edn. New York: John Wiley and sons 756pages

Narongsirikul, S., Mondol, N.H. and Jahren, J. (2013). Depletion-induced Reservoir Compaction in Shallow Overconsolidated Reservoir. EAGE International Workshop on Geomechanics and Energy - The Ground as Energy Source and Storage Lausanne, Switzerland, 26-28 November 2013, Pp. 1 - 5.

Olden, P., Jin, M., Pickup, G., MacKay, E., Hamilton, S., Somerville, J. and Todd, A. (2014).Geomechanical modeling of $\mathrm{CO}_{2}$ geological storage with the use of site specific rock mechanics laboratory data.

Petroleum Geoscience, 20 (4). Pp. 323 - 337.

Olmanson LG, Kloiber SM, Bauer ME, Brezonik PL (2001) Image processing protocol for regional assessments of lake water quality. Public Report series \#14Water Resources Centre and Remote Sensing Laboratory, University of Minnesota St. Paul, MN 5510811 pages.

Orlic, B., van Eijs, R. and Scheffers, B. (2001) Integrated geomechanical modelling for deep subsurface damage. 63rd EAGE meeting. Amsterdam, Extended Abstracts, paper P 604. (2001).

Pratt, W.E. and Johnson, D. W. (1926). Local subsidence of the Goose Creek oilfield. Journal of Geology, Part 1 (Oct. - Nov.) 34(7), 577 - 590.

Poland, J. F. (1984). Guidelines to studies of land subsidence due to groundwater withdrawal. Studies and reports in hydrology, 40. UNESCO

Riel, B., Simons, M., Ponti, D., Agram, P., and Jolivet, R. (2018). Quantifying ground deformation in the Los Angeles and Santa Ana Coastal Basins due to groundwater withdrawal. Water Resources Research, 54. 
Segall, P. (1989). Earthquakes triggered by fluid extraction, Geology, 17, 942-946.

Stacher, P. (1995). Present Understanding of the Niger Delta Hydrocarbon Habitat, in M N Oti and G Postma (Eds.), Geology of Deltas, pp. 257-267, A.A. Balkema, Rotterdam.

Short, K. C. and Stäuble, A. J. (1965). Outline of geology of Niger Delta", American Association of Petroleum Geologists Bulletin, Vol. 51, pp. 761-779.

Sibson (1996). Structural permeability of fluid driven fault fractures meshes. J. of Structural Geology, 18, $1031-1042$.

Sroka A. and Hejmanowski, R. (2006). Subsidence prediction caused by the oil and gas development. 3rd IAG / 12th FIG Symposium, Baden, May 22-24, 2006. Pp. 1 -9

Temizel, C., Kirmaci, H., Incesci, T., Wijaya, Z., Balaji, K., Suhag, A., Ranjith, R., Al-Otaibi, B., Al-Kouh, A., Zhou, Y., and Yegin, C. (2016). An approach to mitigate subsidence in soft rocks through coupling surface tiltmeter and injection/production data. SPE $184107-M S, 1-41$.

Terzaghi, K. (1943). Theoretical soil mechanics. New York: Wiley

Terzaghi, K. (1936). The shearing resistance of saturated soils and the angle between the planes of shear. Proceedings of the International Conference on Soil Mechanics and Foyndation Engineering, Vol. 1: Cambridge Massachusetts USA, $54-56$.

Tingay, M.R.P., Hillis, R. R., Swarbrick, R. E., Morley, C. K., and Damit, A.R.2009. Origin of overpressure and pore pressure prediction in the Baram province, Brunei. AAPG Bull. 93(1) Pp 51 - 74.

\section{Torp, 2011}

Tutle, M. L. W., Charpentier, R. R., Brownfield, M. E. (1999). Chapter A. The Niger delta petroleum system; Niger Delta province, Nigeria, Cameroon and Equatorial Guinea, Africa. US Department of Interior, USGS open file report No. 99 - $50-\mathrm{H}$.

Uko, E. D, Famuyibo, D. A. and Okiongbo, K. (2018). Estimation of Land Surface Subsidence Induced by Hydrocarbon Production in the Niger Delta, Nigeria, using Time-Lapse Orthometric Leveling Data. Mediterranean Journal of Basic and Applied Sciences (MJBAS), Volume 2, Issue 3, Pp. 1-18

van Thienen-Visser, K. and Breunese, J. N. (2015). Induced seismicity of the Groningen gas field: History and recent developments. Leading Edge: Special Section: Injection induced seismicity, 664 - 671.

Wiprut, D. and Zoback, M. D. (2000). Fault reactivation and fluid flow along a previously dormant normal fault in the northern North Sea. Geology, 28, 595-598

Wolfe, C., Russell, C., and Luise, N. (2005). Log based pore volume compressibility prediction - A depwater GOM case study. SPE 95545, pp. 1 - 10. 
Yerkes, R.F. and R.O. (1976). Castle, Seismicity and faulting attributable to fluid extraction, Engineering Geology, 10, 151-167.

Zhang, J. (2011). Pore pressure prediction from well logs: methods, modifications and new approaches: Earth Science Reviews Vol. 108, Pp 50 - 63.

Zheng, (1993). Compressibility of porous rocks under different stress conditions. International Journal of Rock Mechanics and Mining Sciences and Geomechanics Abstracts, 30, (7)., 1184 - 1187

Zimmermann, R. (1991). Compressibility of sandstones. Developments in Petroleum Science 29. Amsterdam: Elsevier Scientific Company

Zimmermanw, R. W., Somerton, W. H. and King, M. S. (1986). Compressibility of porous rocks. Journal of Geophysical Research, Vol. 91, No. B12, pages 12,765-12,777,

Zoback MD (2007) Reservoir geomechanics. New York. Cambridge University Press.505pages.

Zoback, M. D. and Zinke, J. C. (2002). Production induced normal faulting in the Valhall and Ekofisk oil fields. Pure \& Applied Geophysics, 159, 403-420.

\section{Figures}




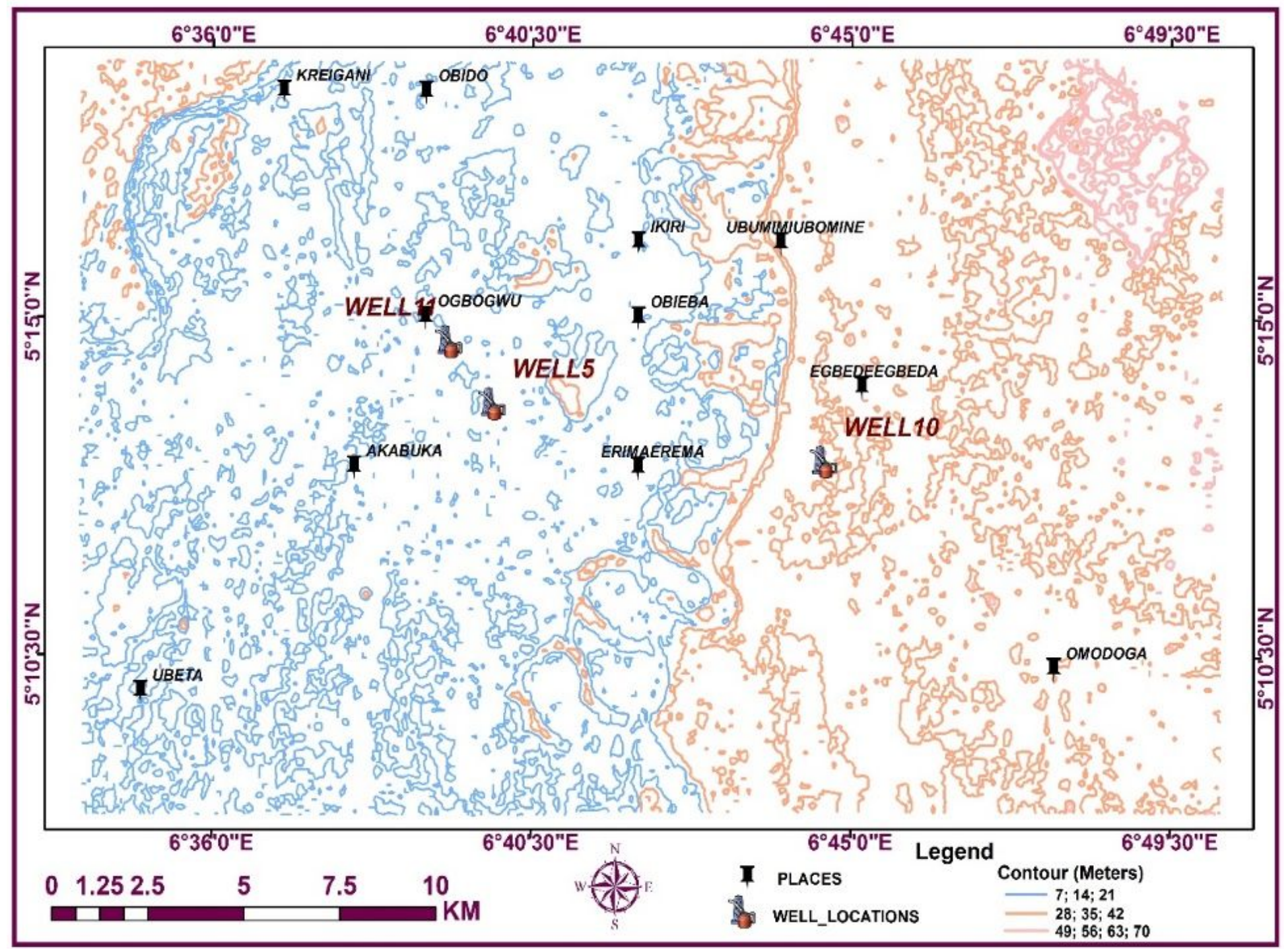

Figure 1

Location of map of the study area showing oil wells and ground elevation contours 


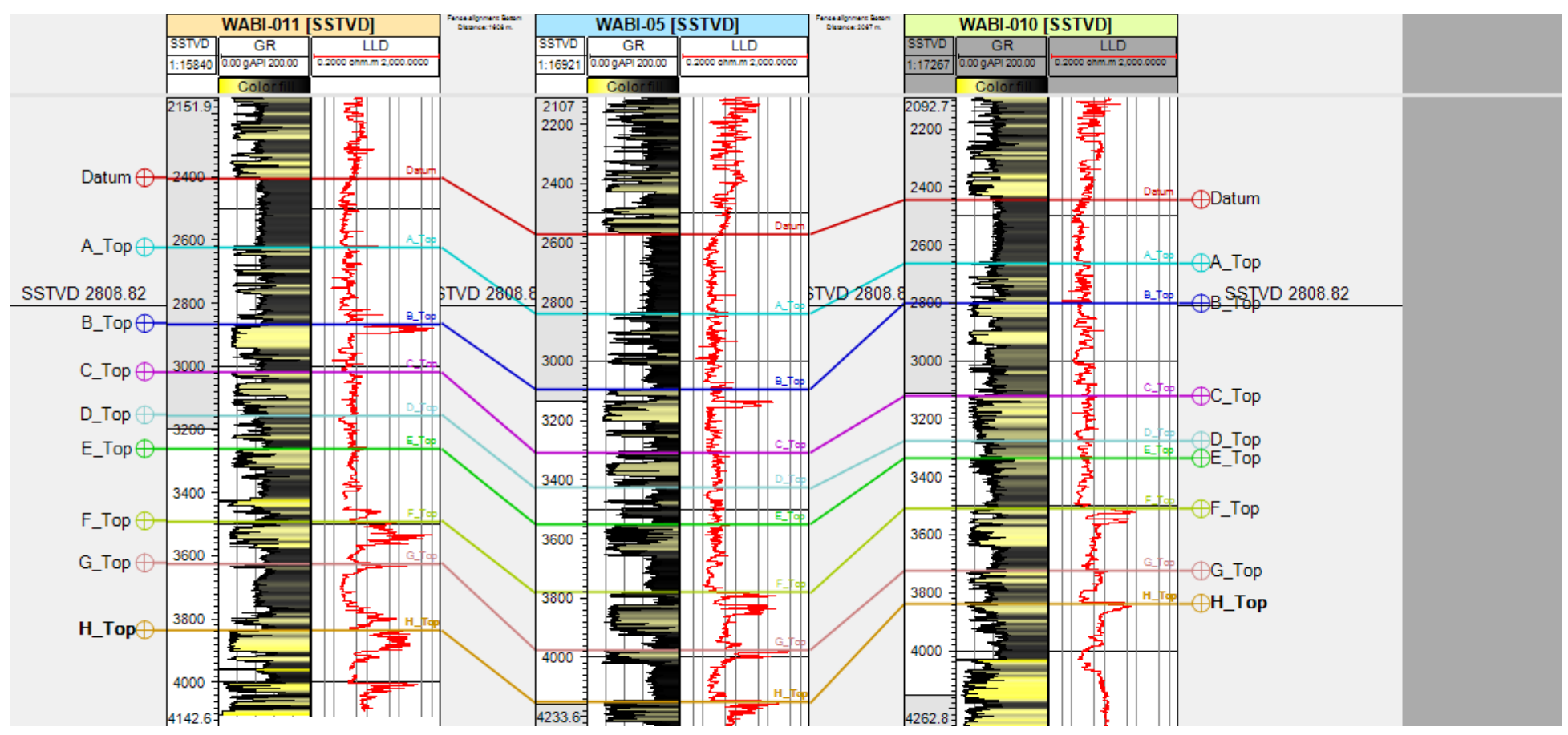

Figure 2

Wireline log correlation in three wells from the oilfield under study depicting a graben structure with NE SW and NW - SE trending faults

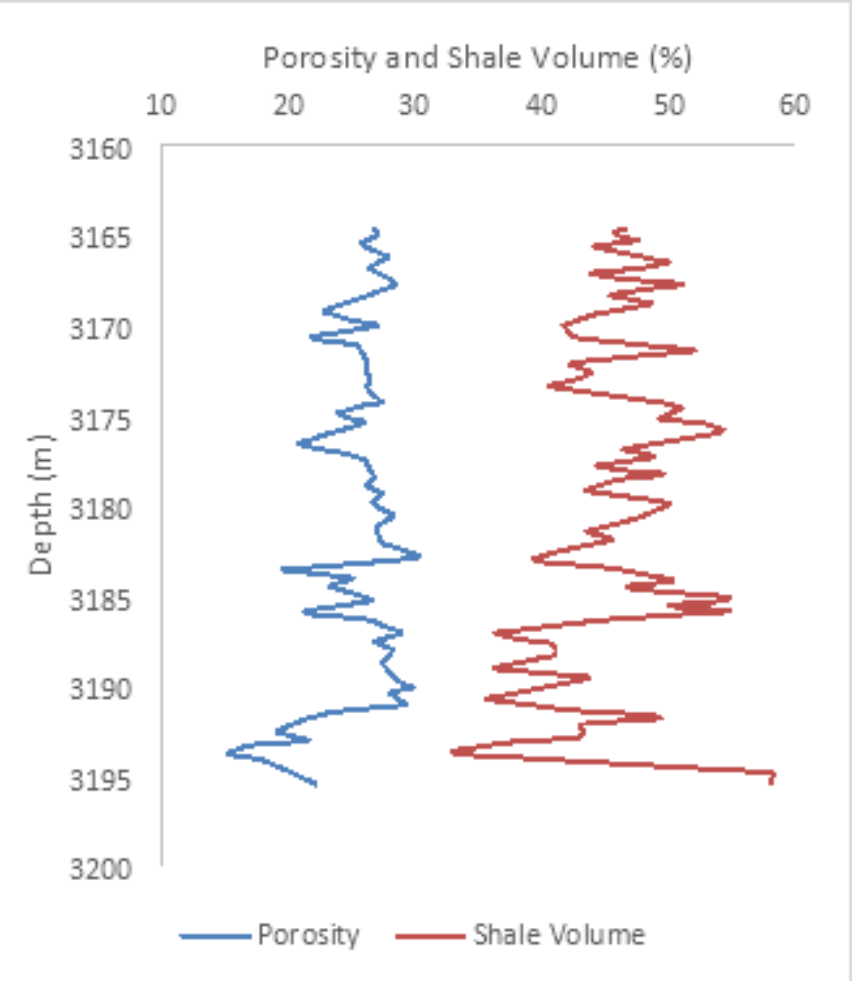

\section{Figure 3}

Typical values of reservoir porosity and shale volume at a depth interval of $3160-3200 \mathrm{~m}$ in well 10 


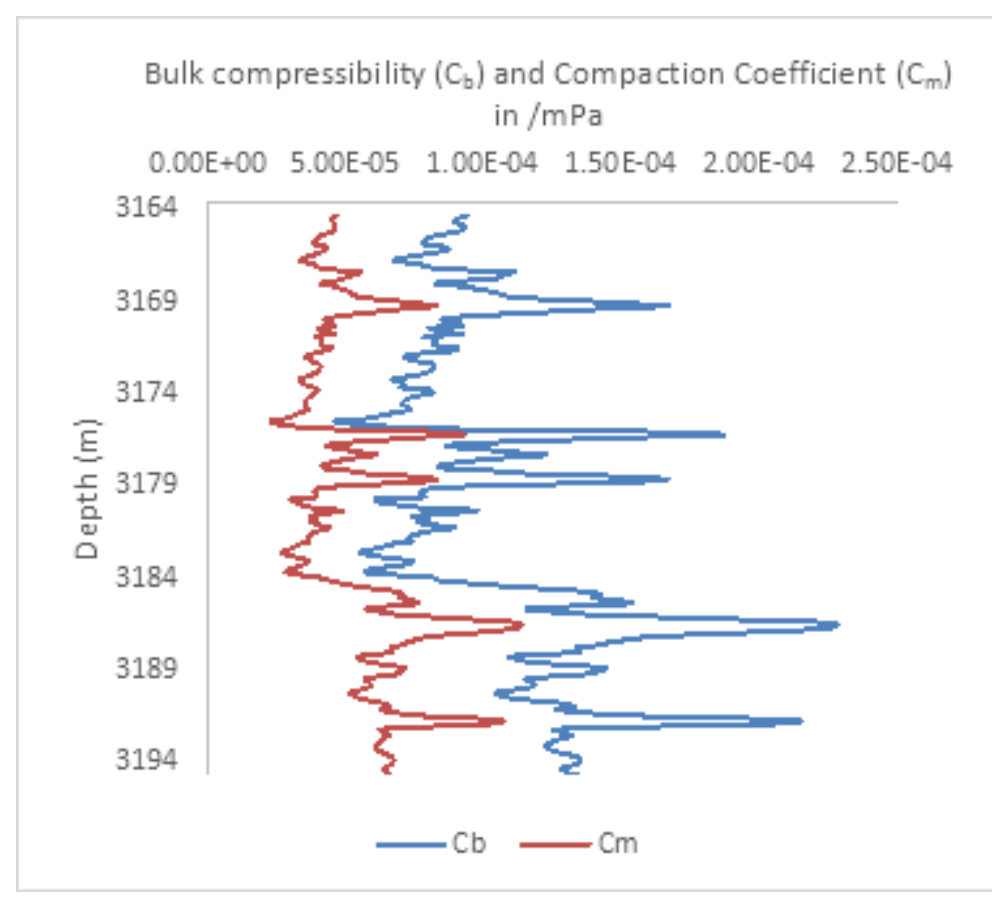

Figure 4

Typical values of bulk compressibility and compaction coefficient of the reservoir rocks in well 10

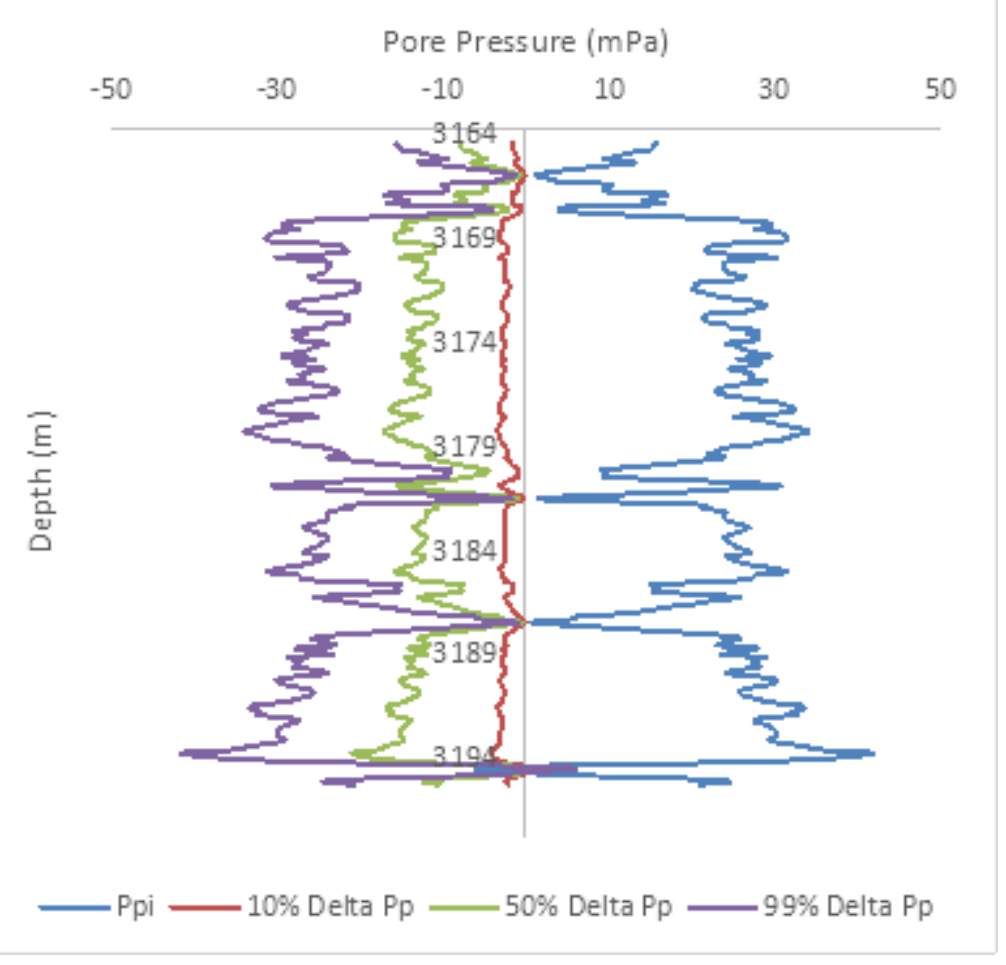

\section{Figure 5}

Typical values of initial pore pressure (Ppi) and pore pressure change at $10 \%, 50 \%$ and $99 \%$ depletion in the reservoir rocks of well 10. 


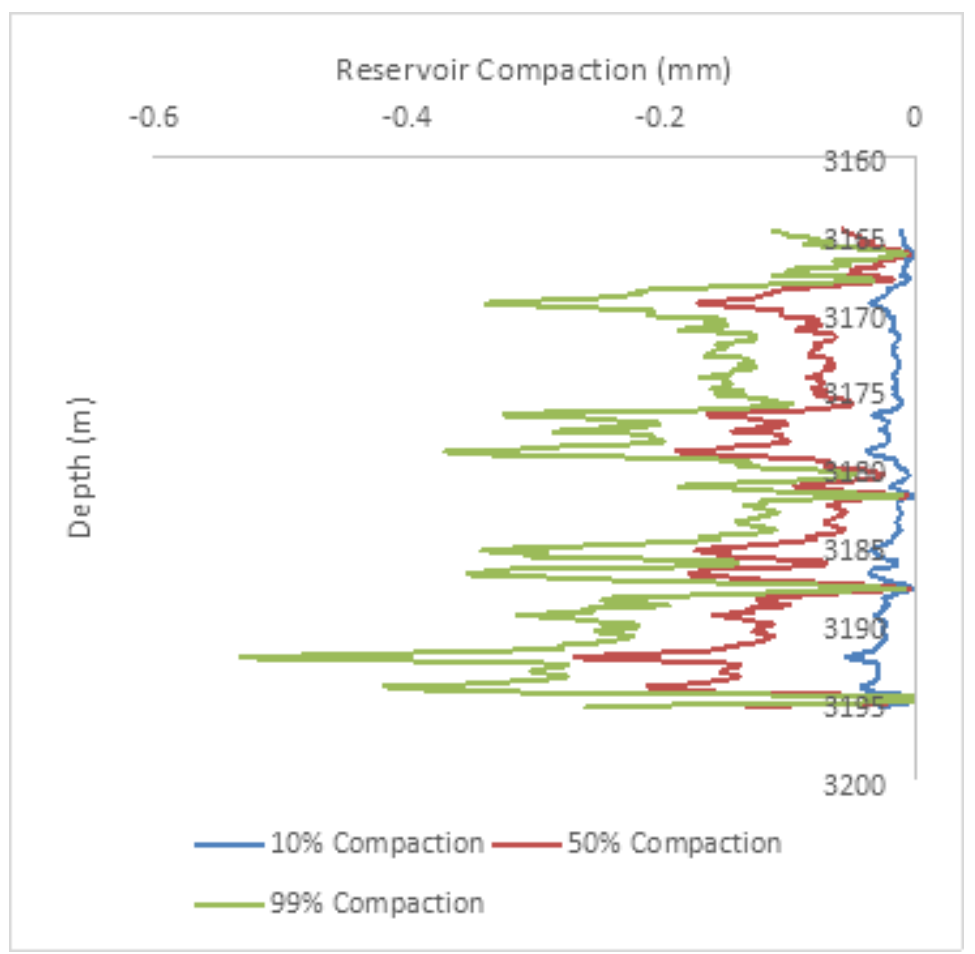

\section{Figure 6}

Typical results of vertical compaction of the reservoir due to pore pressure dissipation at $10 \%, 50 \%$ and $99 \%$ depletion in a reservoir at $3164-3195 m$ depth interval of well 10 .

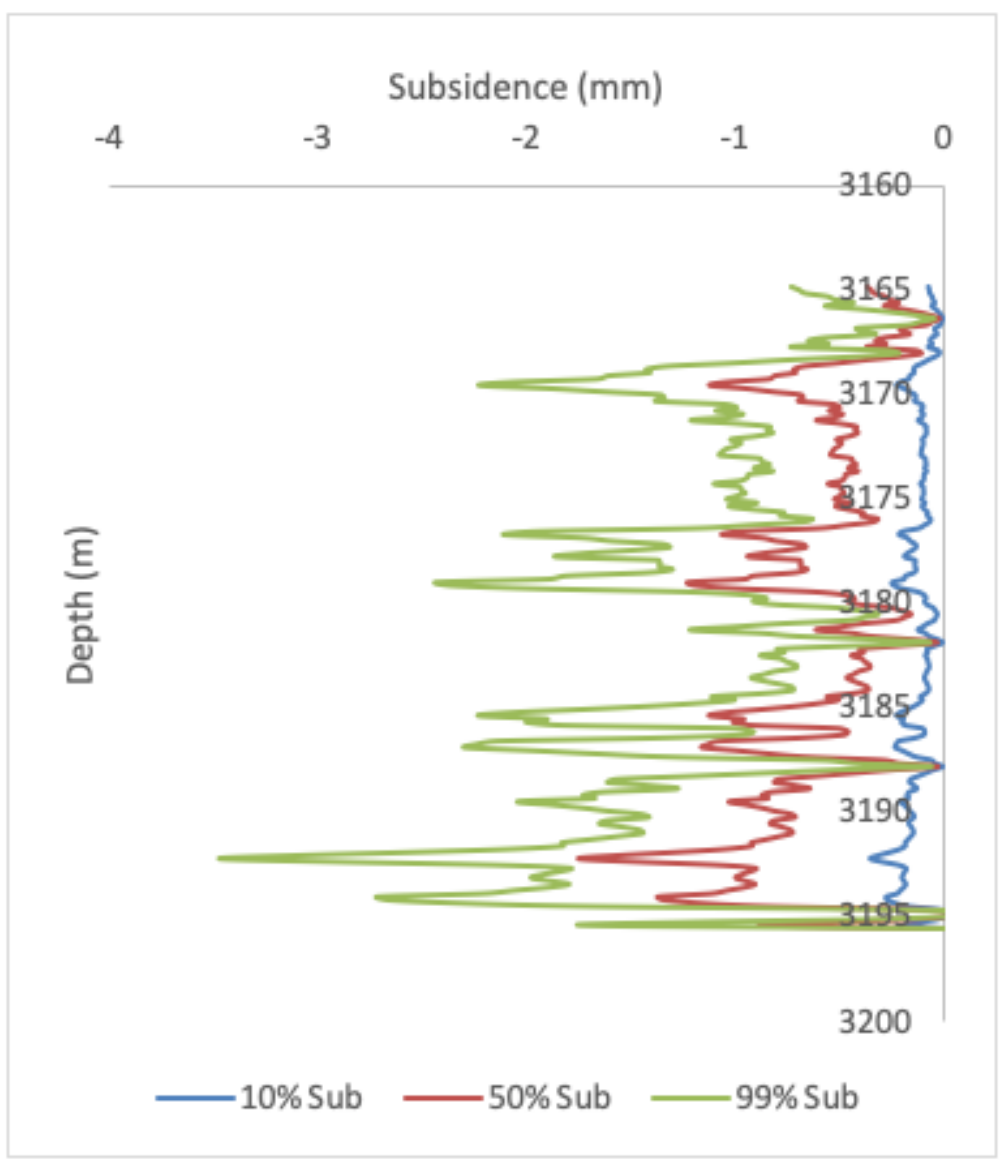




\section{Figure 7}

Typical results of surface subsidence due to pore pressure dissipation at $10 \%, 50 \%$ and $99 \%$ depletion in a reservoir at $3164-3195 m$ depth interval of well 10

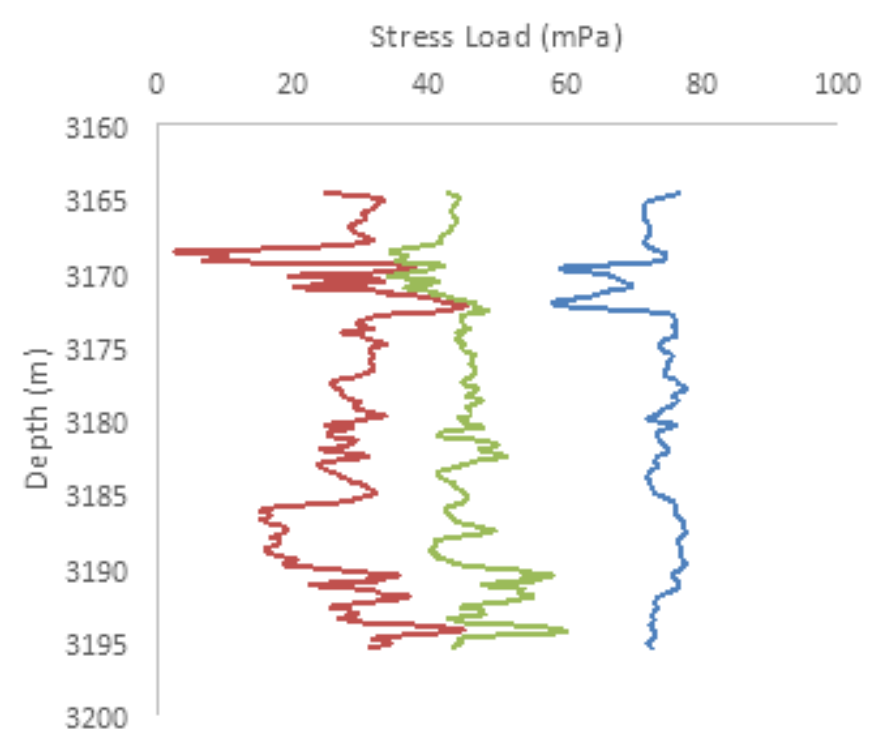

- Overburden load ——Min Hor. Load _— Max Hor. Load

\section{Figure 8}

Variation of stress load depth in a reservoir at $3164-3195 m$ depth interval of well 10

Variation of vertical compaction with formation pressure change in a reservoir at a depth interval of $3164-3195 \mathrm{~m}$

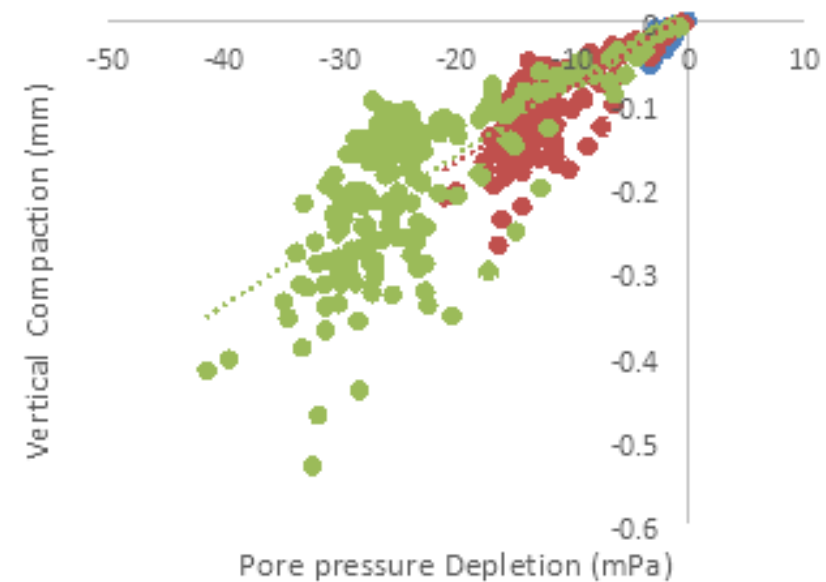

Figure 9

Variation of vertical compaction with pore pressure dissipation at $10 \%, 50 \%$ and $99 \%$ depletion in a reservoir at $3164-3195 m$ depth interval of well 10 
Variation of Subsidence with formation

pressure change in a reservoir at a depth interval of $3164-3195 \mathrm{~m}$

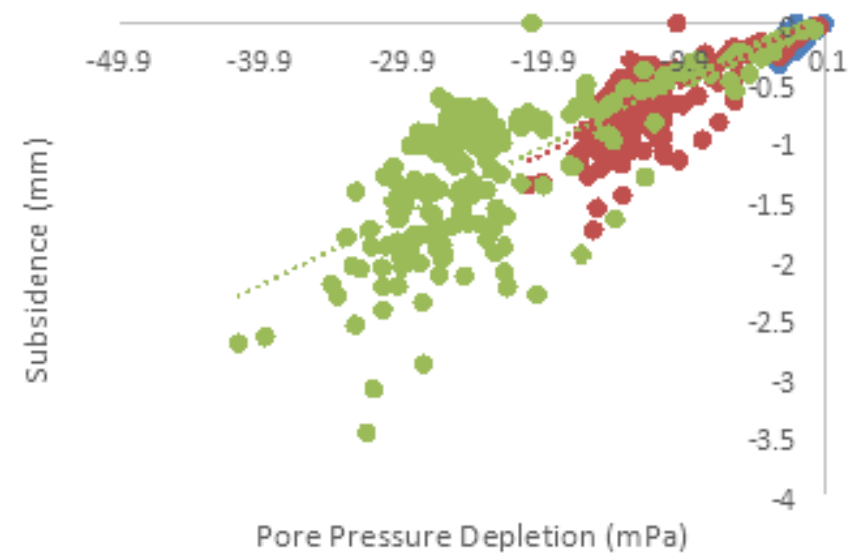

\section{Figure 10}

Variation of subsidence with pore pressure dissipation at $10 \%, 50 \%$ and $99 \%$ depletion in a reservoir at $3164-3195 m$ depth interval of well 10

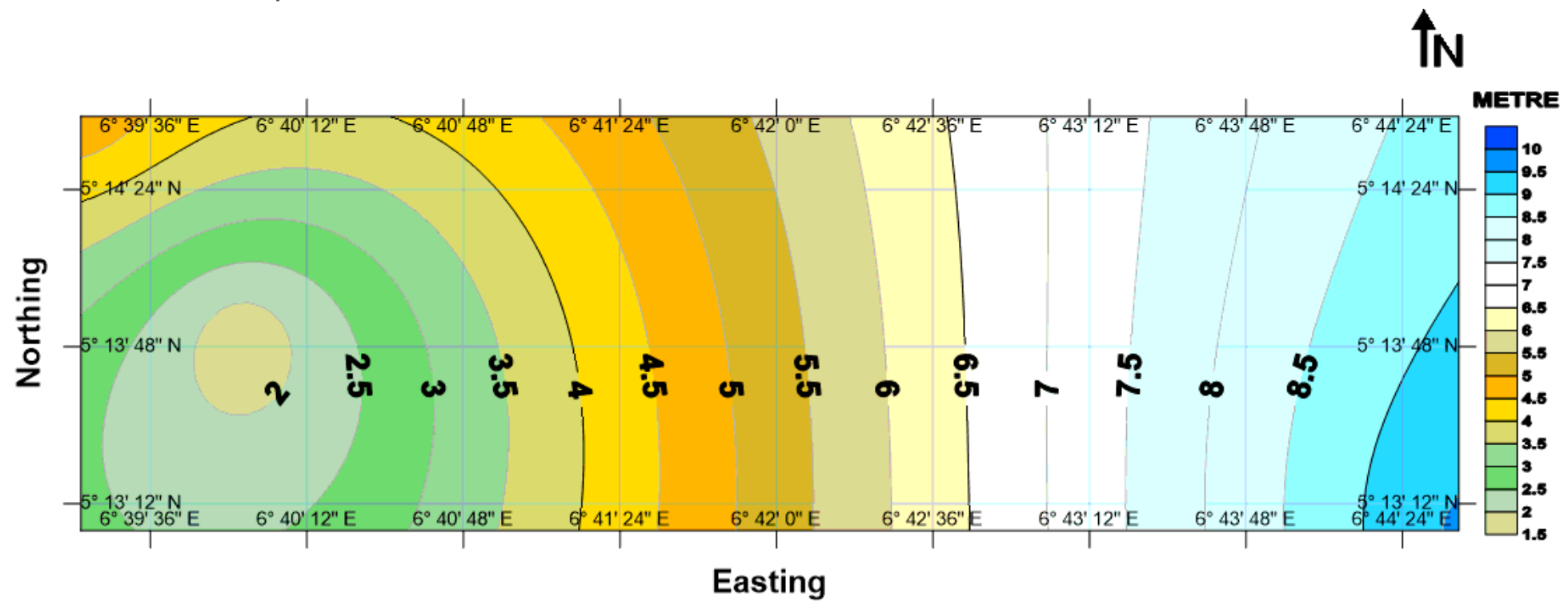

\section{Figure 11}

Typical reservoir subsidence map of the oilfield at 50\% reservoir pressure depletion 


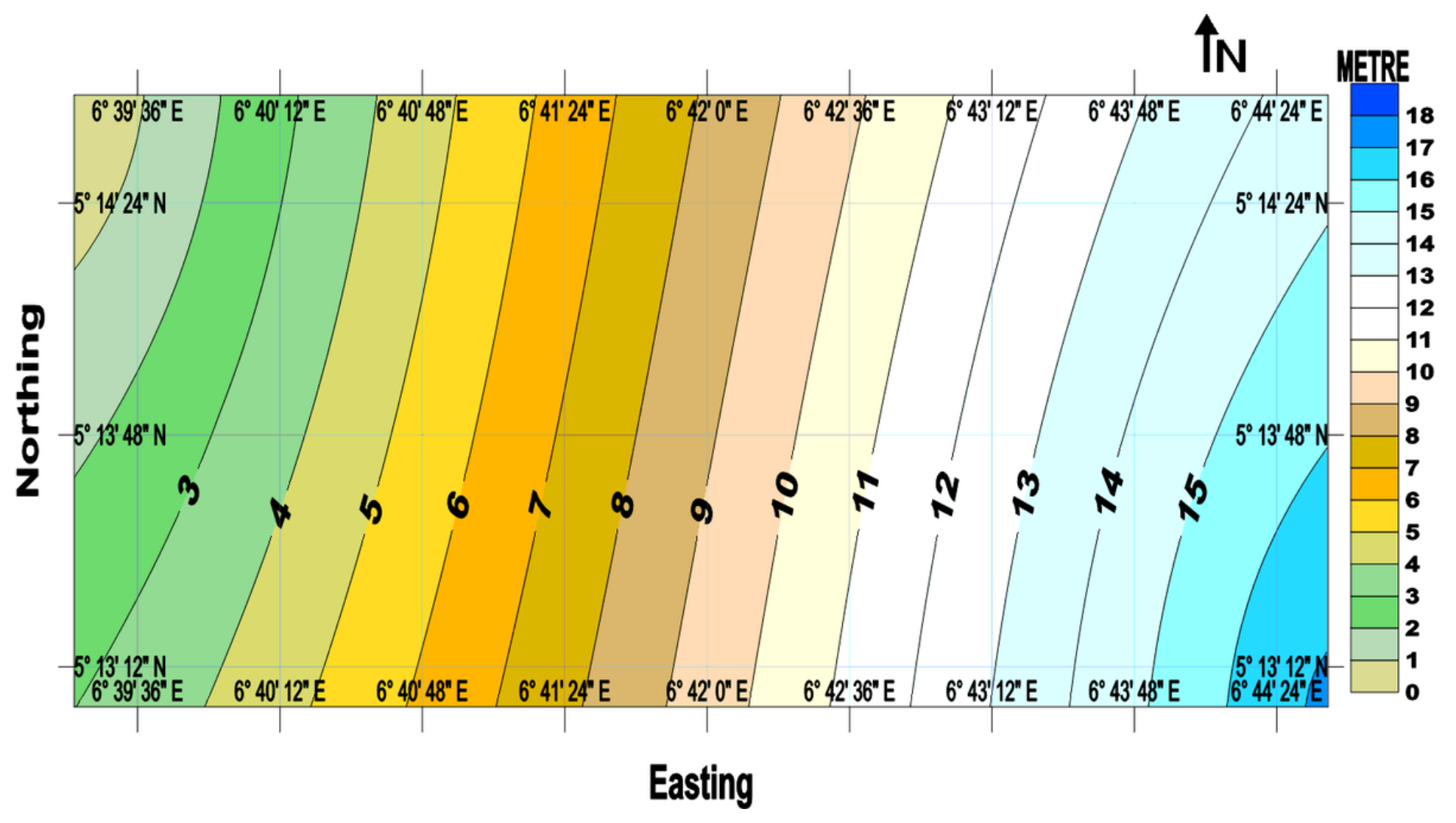

Figure 12

Reservoir subsidence map of the oilfield at $90 \%$ pore pressure depletion

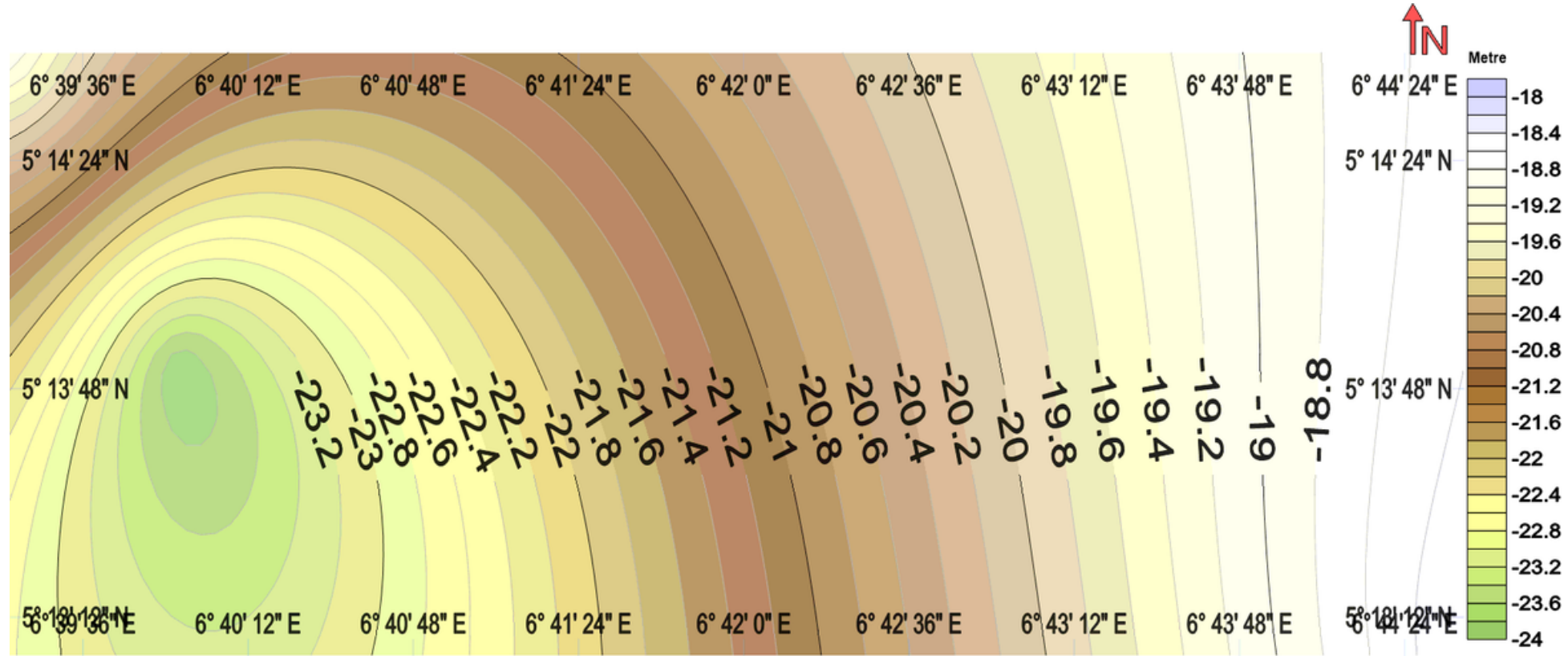

Figure 13

Ground subsidence contour map above an oilfield (1982 - 2018) in the delta 

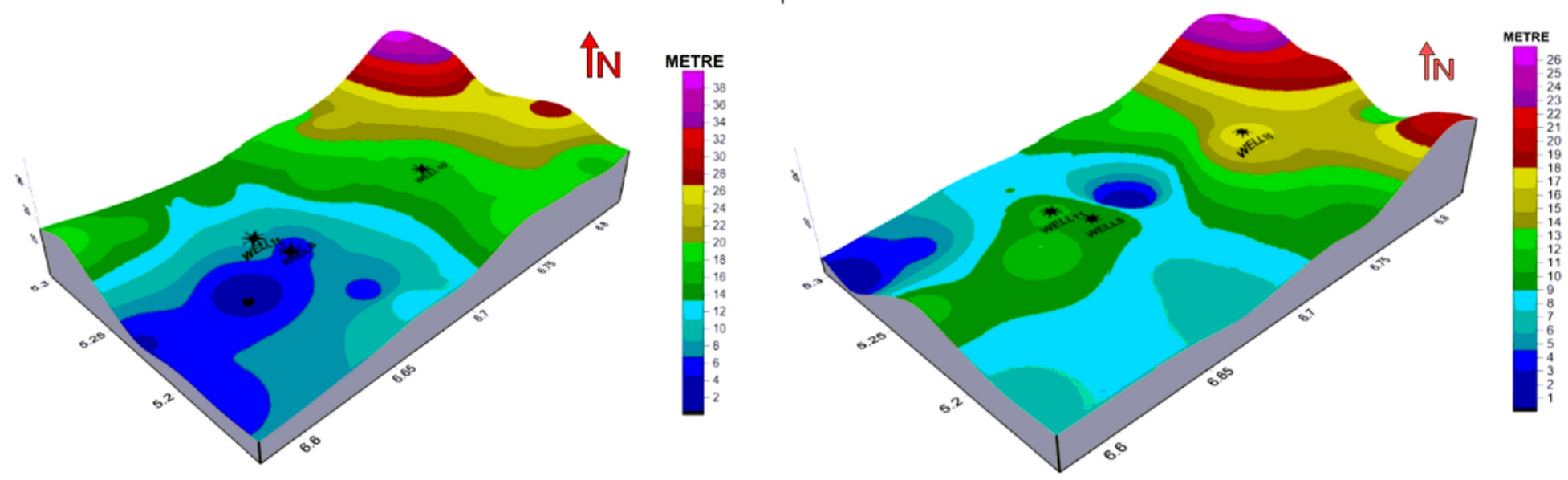

Figure 14

(a) 3D ground elevations display of the oilfield in the year 2018. (b). Vertical ground surface displacement in the year 2018. 